\title{
Impacts of vegetation and palaeohydrological changes on the $n$-alkane composition of a Holocene peat sequence from the Upper Vistula Valley (southern Poland)
}

\author{
Sylwia Skreczko ${ }^{1}$ (D) Artur Szymczyk ${ }^{1}$ [D $\cdot$ Weronika Nadłonek ${ }^{2}$
}

Received: 12 January 2021 / Accepted: 16 May 2021 / Published online: 27 May 2021

(c) The Author(s) 2021

\begin{abstract}
Purpose The analysis of $n$-alkanes in palaeoenvironmental studies of peatlands is mainly limited to ombrogenous peatlands which are a rare feature in the environment. Using $n$-alkane and plant macrofossil analysis, we have tracked changes in the environment in the valley of a large Central European river. We tested the possibilities for applying such studies to low-moor bogs which are the most commonly occurring type of bog in the world.

Materials and methods Representative peat samples were taken from two profiles in a peatland located in the Vistula Valley (southern Poland), and they were analysed for the occurrence and distribution of biomarkers. The distribution of $n$-alkanes was determined using gas chromatography-mass spectrometry (GC-MS). The botanical composition of the samples was determined by analysis of plant macrofossil remains, and the degree of peat decomposition was also determined.

Results and discussion Samples of low-moor peat were characterised by a prevalence of medium- and long-chain $n$-alkane homologues, which is typical for higher plants. The variable values of the CPI, CPI ${ }_{(25-31}$, and the $\mathrm{C}_{23} / \mathrm{C}_{25}$ ratio have provided information on the stages of formation of the Zapadź bog. The source of $n$-alkane differentiation is vegetation change related to palaeohydrological dynamics and palaeoenvironmental conditions within the peatland.

Conclusions We have shown that analysis of $n$-alkanes can be successfully used in low-moor bogs as a complement to palaeobotanical and palaeozoological methods. The bringing together of these types of research enables changes in the ecosystems of large river valleys to be tracked.
\end{abstract}

Keywords $N$-Alkanes $\cdot$ Low-moor peat $\cdot$ Environmental changes $\cdot$ Holocene $\cdot$ Poland

\section{Introduction}

Peat, biogenic sediment formed from partially decayed plant debris, accumulates in constantly wet, acidic, and suboxic to anoxic sedimentary environments. The different types of plant material that participate in the process of peat formation include leaves, rhizomes, roots, and woody parts of vascular plants as well as bryophytes (Rydin and Jeglum

Responsible editor: Jan Schwarzbauer

Artur Szymczyk

artur.szymczyk@us.edu.pl

1 Faculty of Natural Sciences, Institute of Earth Sciences, University of Silesia, Będzińska 60, 41-200 Sosnowiec, Poland

2 Polish Geological Institute - National Research Institute, Królowej Jadwigi 1, 41-200 Sosnowiec, Poland
2013). The composition of peat deposits provides climatic information about the local area and can serve as a useful tool in reconstructing palaeoclimate (Bingham et al. 2010).

Lipids from peat-forming plants can be used as proxies for past changes in bog vegetation because they can persist in a relatively unaltered state, unlike the bulk of the vegetation which is largely composed of readily degradable components such as carbohydrates (Pancost et al. 2002).

The distribution of $n$-alkanes in peat profiles is related to the different types of vegetation that formed the peat. The $n$-alkane content differs greatly between plant species and they are not species-specific molecules (Schellekens and Buurman 2011). Moreover, the amounts of n-alkanes delivered to the sediment by plants may be disproportionate to the quantities of plant biomass present in the peat (Andersson et al. 2011). The results of Ficken et al. $(1998,2000)$ and Pancost et al. (2002) showed that the leaves of some vascular plant species (e.g. of the Ericeaceae family) contain higher 
concentrations of $n$-alkanes than Sphagnum and other moss species. Also, the leaves of deciduous trees are more abundant in n-alkanes than coniferous tree needles. Deciduous trees produce far more biomass than other plants, and their leaves are major contributors of n-alkanes to sedimentary organic matter of terrestrial origin.

Different groups of plants produce leaf wax n-alkanes with differing carbon chain lengths (Nichols et al. 2006). The leaf wax of vascular plants (grasses, sedges, trees, and shrubs) is dominated by long-chain $n$-alkanes with 29-31 carbon atoms per molecule (from $n$-C29 to $n$-C31), whilst Sphagnum leaf wax is dominated by $n$-alkanes with medium chain length (from $n$-C23 to $n$-C25) (Nott et al. 2000; Pancost et al. 2002; Nichols et al. 2006). A dominance of short-chain $n$-alkanes in the hydrocarbon fraction indicates that the sediment was deposited in an aquatic environment and that organic matter occurring there is an autochthonic component (Maliński and Witkowski 1988). The occurrence of $n$-alkanes with 23 carbon atoms in a chain (and to a lesser degree, with 25 carbon atoms in a chain) is not typical for terrestrial conditions (Eglinton and Hamilton 1967), but is commonly observed in different Sphagnum species (Nott et al. 2000; Baas et al. 2000; Pancost et al. 2002).

The diversity of $n$-alkanes may also be related to the variability of ecological conditions (e.g. changes in the water table). One consequence of environmental change is a variation in the species composition of plant communities. During dry periods with a lowered water table, Sphagnum, which does not have a vascular system, cannot obtain water, and this has a negative effect on its growth (Nichols et al. 2009). In such situations, vascular plants contribute more leaf wax to the peat deposit. Conversely, when the water level is high, the oxygenated layer near the surface of the peatland becomes thinner, making conditions difficult for vascular plants (Nichols et al. 2009). Changes of water table levels in the peat can be reflected by the quantity of $\mathrm{C}_{23}$ and $\mathrm{C}_{29} n$-alkanes contained in Sphagnum and vascular plants.

The strong connection between the distribution of plant species and the wetness of the surface of an ombrotrophic mire (Charman 2002; Rydin and Jeglum 2013) leads to the suggestion that the variety of biomarkers originating from plants, when incorporated into peat, can be used to reconstruct past conditions.

The analysis of $\mathrm{n}$-alkanes has been successfully used to reconstruct the changes in the vegetation and palaeohydrology of the peatlands in different climatic zones not only in Europe (e.g. Nichols et al. 2009; Andersson et al. 2011; Ronkainen et al. 2013; Gabov et al. 2017) but also across the world (Zhang et al. 2017). However, the vast majority of these studies concerned ombrotrophic bogs, which are considered the best subjects (e.g. Nichols et al. 2006; Bingham et al. 2010; Schellekens and Buurman 2011; Balascio et al. 2018) for this type of study. The specific conditions that are required for them to form mean that the opportunities for using the analysis of $n$-alkanes are, in practice, limited to the relatively small areas on which they can form (usually watersheds and mountains).

There has been only sporadic use of n-alkane analysis to monitor environmental change in low-moor peatlands, the most prevalent peatlands in the world, and a permafrost area. An example of this type of study is a study of peatlands in the tundra zone (Bol'shezemelskaya Tundra, Russia) by Pastukhov et al. (2018). In response to this, our objective was to reconstruct the vegetation changes and changes in the water table levels in a peatland located in the valley of a large river. With the simultaneous application of plant macrofossil analysis, we also tried to estimate the opportunities for using $n$-alkane analysis to track vegetation and palaeohydrological change in inherently deficient ombrotrophic areas of peatland in which low-moor and transitional peatlands are dominant.

\section{Methodology and materials}

\subsection{Study area}

The peatland that was investigated, Zapadź, is located in the valley of the Upper Vistula River in southern Poland, near Góra village in the Miedźna commune ( $49^{\circ} 59^{\prime} 4.8^{\prime \prime} \mathrm{N}, 19^{\circ}$ $26^{\prime} 14.2^{\prime \prime} \mathrm{E}$ ) (Fig. 1). It was formed in a palaeomeander hollow that occupies an area of about 19 ha and is surrounded on three sides by a high embankment. The peatland is a living low-moor bog mainly overgrown with rush vegetation (with the dominance of Carex spp.). The maximum thickness of sediments is $4 \mathrm{~m}$. The eastern edge of the bog is located about $500 \mathrm{~m}$ from the strongly meandering river Vistula.

\subsection{Sampling}

For the purposes of this study, two peat cores were collected in 2016 from different parts of the peatland, the $\mathrm{Z} 1$ core $(3.35 \mathrm{~m})$ situated in the north-western part of the mire, and the $\mathrm{Z} 2$ core $(1.50 \mathrm{~m})$ in its south-eastern part (Fig. 1). The cores for sediment analysis were collected using an Instorf auger with a $5-\mathrm{cm}$ diameter core sampler which was $50 \mathrm{~cm}$ in length. The samples for analysis were selected to reflect changes in the botanical composition of the core sediments. These changes were determined using plant macrofossil analysis.

\subsection{Plant macrofossil analysis}

An analysis was carried out of the species composition in 12 samples of the peat, each with a volume of $20 \mathrm{~cm}^{3}$ and 


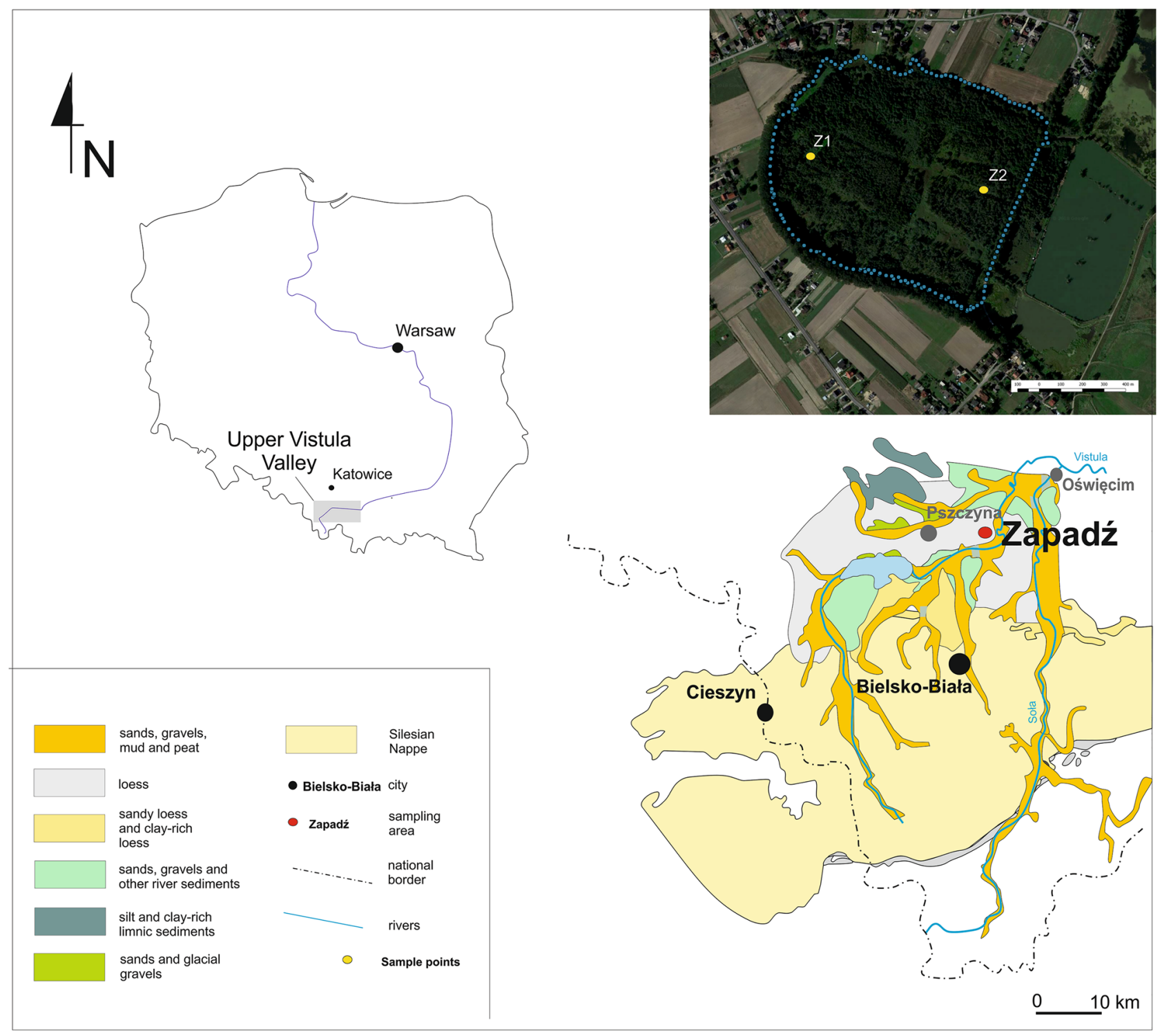

Fig. 1 The location of the study peatland showing the sites of the cores

mainly selected at 5-cm intervals along the core. Samples were taken from the depths at which there were changes in the types of peat in the cores. In order to separate the macrofossils, the peat was rinsed using a sieve with a mesh size of $0.2 \mathrm{~mm}$. The plant macroremains were scored using a stereoscopic microscope. The degree of peat decomposition was defined according to the van Post scale (Rydlin and Jeglum 2013).

\subsection{Gas chromatography-mass spectrometry}

Eight samples from the $\mathrm{Z} 1$ profile and four samples from the Z2 profile were subjected to GC-MS analysis. Each sample had a dry weight of about $10 \mathrm{~g}$. After drying in the laboratory, the samples were first crushed in an agate mortar; then, organic matter was extracted using a dichloromethane and methanol mixture (5:1, vol:vol) in a Dionex ASE 350 solvent extractor. Extracts were separated into aliphatic, aromatic, and polar fractions by modified column chromatography according to Bastow et al. 2007. Silica-gel was first activated at $110{ }^{\circ} \mathrm{C}$ for $24 \mathrm{~h}$ hand then put into Pasteur pipettes. The eluents used for collection of the fractions were $n$-pentane for aliphatic hydrocarbons, $n$-pentane and dichloromethane for the aromatic fraction (7:3 vol:vol), and dichloromethane and methanol for the polar fraction (1:1 vol:vol) (Rybicki et al. 2016). Fractions of selected peat samples were analysed using an Agilent Technologies 7890A gas chromatograph and Agilent 5975C Network mass spectrometer. The GC column outlet was connected directly to the ion source of the Triple-Axis 
Detector (MSD) (Rybicki et al. 2016). The GC-MS interface temperature was $280{ }^{\circ} \mathrm{C}$, while the ion source and quadrupole analyser were at $230{ }^{\circ} \mathrm{C}$ and $150{ }^{\circ} \mathrm{C}$, respectively. Helium (6.0 Grade) was used as a carrier gas at a constant flow of $2.6 \mathrm{ml} \mathrm{min}{ }^{-1}$. Separation was on either of the fused silica capillary columns:

- J\&W HP5-MS (60 m $0.32 \mathrm{~mm}$ i.d., 0.25- $\mu \mathrm{m}$ film thickness) coated with a chemically bonded phase (5\% phenyl, 95\% methylsiloxane). The GC oven temperature was programmed from $45^{\circ} \mathrm{C}(1 \mathrm{~min})$ to $100{ }^{\circ} \mathrm{C}$ at $20^{\circ} \mathrm{C} /$ min, then to $300{ }^{\circ} \mathrm{C}$ (held $60 \mathrm{~min}$ ) at $3{ }^{\circ} \mathrm{C} / \mathrm{min}$. Solvent delay $=10 \mathrm{~min}$.

- J\&W DB35-MS (60 m $0.25 \mathrm{~mm}$ i.d., $0.25 \mu \mathrm{m}$ film thickness) coated with a chemically bonded phase (35\% phenyl, 65\% methylsiloxane). The GC oven temperature was programmed from $50{ }^{\circ} \mathrm{C}(1 \mathrm{~min})$ to $120^{\circ} \mathrm{C}$ at $20^{\circ} \mathrm{C} /$ min, then to $300{ }^{\circ} \mathrm{C}$ (held $60 \mathrm{~min}$ ) at $3{ }^{\circ} \mathrm{C} / \mathrm{min}$. Solvent delay $=15 \mathrm{~min}$.

Mass spectra were recorded from $\mathrm{m} / \mathrm{z} 45-550$ (0-40 min) and $\mathrm{m} / \mathrm{z}$ 50-700 (> $40 \mathrm{~min}$ ). The mass spectrometer was operated in the electron impact mode (ionisation energy $70 \mathrm{eV}$ ) (Rybicki et al. 2016).

The results were presented in terms of five geochemical proxies. Carbon Preference Index (CPI) ratios (Kotarba et al. 1994) for $n$-alkanes containing from 17 to 31 carbon atoms per molecule were calculated as:

CPI-the value of the Carbon Preference Index for the $n$-alkanes $\mathrm{C}_{17}-\mathrm{C}_{31}$ after Kotarba et al. (1994).

$C P I=\frac{\left(C_{17}+C_{19} \ldots+C_{27}+C_{29}\right)+\left(C_{19}+C_{21} \ldots+C_{29}+C_{31}\right)}{\left[2\left(C_{18}+C_{20} \ldots+C_{28}+C_{30}\right)\right]}$

$\mathrm{CPI}_{25-31}$ (Kotarba et al. 1994) was calculated in a similar way for $n$-alkanes containing 25-31 carbon atoms per molecule as

$C P I_{(25-31)}=\frac{\left(C_{25}+C_{27}+C_{29}\right)+\left(C_{27}+C_{29}+C_{31}\right)}{\left[2\left(C_{26}+C_{28}+C_{30}\right)\right]}$

We also calculated the $\mathrm{SCh} / \mathrm{LCh}$ (short-chain/long-chain) quotient, which is the proportion of short-chain homologue $n$-alkanes with 17, 18, and 19 carbon atoms per molecule to long-chain $n$-alkanes with 27,28 , and 29 carbon atoms per molecule, as.

$S c h / L C H=\left(n C_{17}+\left(n C_{18}+\left(n C_{19}\right) /\left(\left(n C_{27}+\left(n C_{28}+\left(n C_{29}\right)\right.\right.\right.\right.\right.$

Finally, we derived $\mathrm{C}_{23} / \mathrm{C}_{31}$ (n-alkanes with 23 carbon atoms per molecule as a proportion of $n$-alkanes with 31 carbon atoms per molecule; Pancost et al., 2002) and $n-\mathrm{C}_{\max }$ (the maximum $n$-alkane content). (Rybicki et al., 2016)

\section{Results}

\subsection{Plant macrofossils analysis}

The results of the analysis of plant macrofossil remains are shown in Tables 1 and 2. The composition of the peat from Zapadź showed considerable variation (Figs. 2a and 3a). Three types of low-moor peat have been identified in the profiles: Alnioni, Magnocaricioni, and Bryalo-Parvocaricioni. The upper of the layers for the two profiles showed the greatest variety of plant macroremains mostly comprising Carex spp. with smaller quantities of Phragmites australis and brown mosses. Betula sect. Albae, Eriophorum vaginatum, and Juncus spp. were also identified in the upper of the layers. The main component of the middle part of the profiles was Carex spp. The base of the profile Z1 consisted of moss peat including Sphagnum sp. with Carex sp., Eriophorum vaginatum, and Phragmites australis. In case of the $\mathrm{Z} 2$ core, it was sedge peat with a small share of brown moss remains and Phragmites australis. The wood, seeds, and fruits of Betula sect. Albae were recognised almost throughout the whole profiles of $\mathrm{Z} 1$ and $\mathrm{Z} 2$.

\subsection{Gas chromatography-mass spectrometry}

The peat samples studied were dominated by mediumchain $\left(n-\mathrm{C}_{23}\right.$ and $\left.n-\mathrm{C}_{25}\right) n$-alkane homologues (typical for Sphagnum) and long-chain $\left(n-\mathrm{C}_{27}\right.$ and $\left.n-\mathrm{C}_{29}\right) n$-alkane homologues which are characteristic of higher plant waxes (Table 3, marked in orange; Figs. 2b, 3b). Moreover, elevated values of $n$ - $C_{21}$ were observed in samples Z1/5 (73.9\%) and Z1/7 (100\%). The quantities and distributions of $n$-alkanes varied within and between the two peat cores. The percentage content of $n-\mathrm{C}_{23}$ compounds ranged from $8.2 \%(\mathrm{Z} 1 / 7)$ to $100 \%(\mathrm{Z} 1 / 5$ and $\mathrm{Z} 2 / 1)$, that of $n$ $\mathrm{C}_{25}$ compounds from $34.8 \%(\mathrm{Z} 2 / 4)$ to $100 \%(\mathrm{Z} 1 / 1)$, that of $n$ - $\mathrm{C}_{27}$ compounds from $63.3 \%$ (Z1/7) to $100 \%$ (Z1/2, $\mathrm{Z} 1 / 3, \mathrm{Z} 1 / 4, \mathrm{Z} 1 / 6, \mathrm{Z} 1 / 8, \mathrm{Z} 2 / 2, \mathrm{Z} 2 / 3, \mathrm{Z} 2 / 4)$, and that of $n$ $\mathrm{C}_{29}$ compounds from $24.1 \%$ (Z1/7) to $79.5 \%$ (Z1/2). In all of the samples, $n$ - $\mathrm{C}_{27}$ and $n$ - $\mathrm{C}_{25} n$-alkanes were clearly present in significant quantities (Table 3 ).

In some samples, the occurrence of $n$-alkanes was not completely compatible with the occurrence of plant macrofossil remains. For example, the $n$-alkanes in Sample Z1/5 were dominated by $n-\mathrm{C}_{23}$ and $n-\mathrm{C}_{25}$ compounds which suggest Sphagnum spp. content, but the macrofossils were mainly from Carex spp. (a vascular plant) along with some Phragmites australis and a small fraction of brown mosses. Similarly, in the uppermost layer of core Z1 (Sample Z1/1), the high content of $n-\mathrm{C}_{23}$ and $n-\mathrm{C}_{25}$ $n$-alkanes (Table 3 ) indicates that the main component 
Table 1 Species composition of the peat samples (Z1 core)

Depth (m) Species composition of peat

0.0-0.05 Carex sp. 73\% (mainly roots), Phragmites australis 11\% (roots and rhizomes), wood and bark of Betula sp. 3\%, other 13\% (including seeds and fruits: Betula sect. Albae, Bidens tripartita, Carex sp., Eleocharis palustris, Juncus sp., Menyanthes trifoliata, Rannunculus sp.

0.10-0.15 Carex sp. 75\% (mainly roots), Brown mosses 8\%, wood and bark 12\% (including Alnus glutinosa and Betula sp.), Eriophorum vaginatum 2\% (mainly leaves), other 6\% (including Phragmites australis (roots and rhizomes), leaves of Sphagnum sp., and seeds and fruits: Betula sect. Albae, Carex sp., Juncus sp, Polygonum hydropiper, Scirpus sylvaticus

0.45-0.50 Carex sp. 71\% (mainly roots), Brown mosses 18\%, Phragmites australis 5\% (roots and rhizomes), wood 2\% (including Alnus glutinosa and Betula sp.), other 4\% (including Eriophorum sp. (mainly leaves), leaves of Sphagnum sp. and seeds and fruits: Betula sect. Albae, Rannunculus sp.)

0.60-0.65 Carex sp. 75\% (mainly roots), wood and bark15\% (including Alnus glutinosa, Betula sp., Pinus sylvestris), Phragmites australis 4\% (roots and rhizomes), other 6\% (including: Brown mosses, Eriophorum sp. (mainly leaves), leaves of Sphagnum sp., needles of Pinus sylvestris and seeds and fruits: Betula sect. Albae, Carex sp., Scirpus sylvaticus

0.70-0.75 Carex sp. 76\% (mainly roots), wood and bark 17\% Alnus glutinosa, Betula sp. (mainly A. glutinosa), Phragmites australis 2\% (roots and rhizomes), other 5\% (including: rhizomes of Typha sp. and Equisetum sp,. leaves of Sphagnum sp, Brown mosses and seeds and fruits: Betula sect. Albae, Carex sp., Epilobium sp., Juncus sp.)

1.05-1.10 Wood and bark 48\% Alnus glutinosa (mainly) and Betula sp., Carex sp. 37\% (mainly roots), Phragmites australis 3\% (roots Z1/4 and rhizomes), other 12\% (including: rhizomes of Typha sp. and Equisetum sp. and seeds and fruits: Urtica dioica and Carex sp.

1.35-1.40 Carex sp. 87\% (mainly roots), Phragmites australis 5\% (roots and rhizomes), Brown mosses 2\%, wood 2\% (including Alnus glutinosa and Betula sp.), other 4\% (including seeds: Lycopus europaeus and sclerotia of Cenococcum geophilum and coals)

1.55-1.60 Carex sp. 83\% (mainly roots), Phragmites australis 8\% (roots and rhizomes), and other 9\% (including: Brown mosses, wood (Alnus glutinosa and Betula sp., seeds and fruits: Betula sect. Albae, Carex sp., Rannunculus sp. and sclerotia of Cenococcum geophilum

1.90-1.95 Carex sp. 90\% (mainly roots), Phragmites australis 5\% (roots and rhizomes), other 5\% (including: Brown mosses, Eriophorum sp. (mainly leaves), wood (mainly Betula sp.) and seeds and fruits: Betula sect. Albae and Rannunculus sp.

2.10-2.15 Brown mosses 48\%, Carex sp. 39\% (mainly roots), Phragmites australis 2\% (roots and rhizomes), wood of Betula sp. $2 \%$, other 9\% (including fruits: Betula sect. Albae)

2.50-2.55 Carex sp. 80\% (mainly roots), Brown mosses 2\%, wood of Betula sp. 2\%, other 16\% (including: Phragmites australis (mainly roots and rhizomes), Eriophorum vaginatum (mainly leaves), leaves of Sphagnum sp. and seeds and fruits: Betula sect. Albae, Carex sp., Epilobium sp., Juncus sp., Polygonum hydropiper, Rubus sp.

2.70-2.75 Carex sp. 83\% (mainly roots), Brown mosses 9\%, Phragmites australis 2\% (roots and rhizomes), wood of Betula sp. 2\%, other 4\% (including: Eriophorum sp. (mainly leaves) and fruits: Betula sect. Albae

3.00-3.05 Brown mosses 52\%, Carex sp. 40\% (mainly roots), wood of Betula sp. 2\%, and other 6\% (including: Phragmites australis (mainly roots and rhizomes, Eriophorum sp. (mainly leaves), fruits: Betula sect. Albae,

3.25-3.30 Brown mosses 67\%, Carex sp. 24\% (mainly roots), Phragmites australis $2 \%$ (mainly roots and rhizomes), and other $7 \%$ (including Eriophorum sp. (mainly leaves), wood (mainly Betula sp.), seeds and fruits: Betula sect. Albae, Carex sp., Menyanthes trifoliata)

3.30-3.35 Brown mosses 75\%, Carex sp. 12\% (mainly roots), Phragmites australis $2 \%$ (mainly roots and rhizomes), and other $6 \%$ (including: Eriophorum sp. (leaves mainly), wood (mainly Betula sp.), seeds and fruits: Betula sect. Albae, Carex sp., Menyanthes trifoliata, Rannunculus sp.)

of the peat is Sphagnum spp., but the primary macrofossil species identified within this layer was Carex spp. Domination of long-chain $n$-alkane homologues was explicit and confirmed by values of $\mathrm{SCh} / \mathrm{LCh}(3)$ ranging from 0 to 0.15 (Figs. 2c, 3c). Among long-chain homologues, there was a significant domination of $n$-alkanes with an odd number of carbon atoms in the chain, which was confirmed by values of CPI (1) and $\mathrm{CPI}_{25-31}(2)>4$ in all samples. CPI values significantly above 1.0 , odd
$\mathrm{Z} 1 / 1$

preference, indicate low thermal maturity (Ruan et al., $2018)$. The highest values of CPI (>10) were noted in samples $\mathrm{Z} 1 / 3, \mathrm{Z} 1 / 8$, and $\mathrm{Z} 2 / 4$, whereas high values of $\mathrm{CPI}_{25-31}$ were observed in samples $\mathrm{Z} 1 / 3, \mathrm{Z} 1 / 6, \mathrm{Z} 1 / 8, \mathrm{Z} 2 / 2$, and $\mathrm{Z} 2 / 4$ (Figs. 2c, 3c). In the $\mathrm{Z} 1$ profile, $\mathrm{C}_{23} / \mathrm{C}_{31}$ was in the range 1.1-3.8, with the exception of sample $\mathrm{Z} 1 / 8$ (ratio equalling 33.9) (Table 3). The Z2 profile does not show such outliers instead with values of the ratio which range from 1.6 to 5.4 (Table 3). 
Table 2 Species composition of the peat samples ( $\mathrm{Z} 2$ core)

\begin{tabular}{|c|c|c|}
\hline Depth (m) & Species composition of peat & Sample \\
\hline $0.0-0.05$ & $\begin{array}{l}\text { Carex sp. } 68 \% \text { (mainly roots), Phragmites australis } 14 \% \text { (roots and rhizomes), wood and bark } 4 \% \text { (including Betula sp., } \\
\text { Salix sp.), other } 15 \% \text { (including: leaves of Sphagnum sp., Brown mosses, seeds and fruits: Betula sect. Albae, Carex sp., } \\
\text { Eleocharis palustris, Juncus sp.) }\end{array}$ & $\mathrm{Z} 2 / 1$ \\
\hline $0.30-0.35$ & $\begin{array}{l}\text { Carex sp. } 72 \% \text { (mainly roots), Brown mosses } 12 \% \text {, wood and bark } 4 \% \text { (including Alnus glutinosa and Betula sp.), Eriopho- } \\
\text { rum sp. 3\% (mainly leaves), other } 9 \% \text { (including Phragmites australis (roots and rhizomes), leaves of Sphagnum sp., and } \\
\text { seeds and fruits: Betula sect. Albae, Carex sp., Juncus sp.) }\end{array}$ & \\
\hline $0.40-0.45$ & $\begin{array}{l}\text { Carex sp. } 67 \% \text { (mainly roots), Brown mosses } 20 \% \text {, wood } 6 \% \text { (including Alnus glutinosa and Betula sp.), Phragmites aus- } \\
\text { tralis } 3 \% \text { other } 4 \% \text { (including Eriophorum sp. (mainly leaves), leaves of Sphagnum sp. and seeds and fruits: Betula sect. } \\
\text { Albae, Juncus sp., Carex sp.) }\end{array}$ & $\mathrm{Z} 2 / 2$ \\
\hline $0.50-0.55$ & $\begin{array}{l}\text { Carex sp. } 73 \% \text { (mainly roots), wood and bark7\% (including Alnus glutinosa, Betula sp.), Brown mosses 5\%, Phragmites } \\
\text { australis } 4 \% \text { (roots and rhizomes), other 11\% (including leaves of Sphagnum sp., and seeds and fruits: Betula sect. Albae, } \\
\text { Carex sp, Lycopus europaeus) }\end{array}$ & \\
\hline $0.75-0.80$ & $\begin{array}{l}\text { Carex sp. } 71 \% \text { (mainly roots), wood and bark } 13 \% \text { Alnus glutinosa, Betula sp. (mainly A. glutinosa), Typha sp. 5\% (rhi- } \\
\text { zomes), Phragmites australis } 1 \% \text { (roots and rhizomes), other } 10 \% \text { (including Brown mosses, leaves of Sphagnum sp., and } \\
\text { seeds and fruits: Betula sect. Albae, Carex sp., Juncus sp.) }\end{array}$ & $\mathrm{Z} 2 / 3$ \\
\hline $1.05-1.10$ & $\begin{array}{l}\text { Carex sp. } 68 \% \text { (mainly roots), wood and bark } 17 \% \text { Alnus glutinosa, Betula sp., Salix sp. (mainly A. glutinosa), other } 15 \% \\
\text { (including: rhizomes of Typha sp. Phragmites australis (roots and rhizomes) seeds and fruits: Carex sp., Lycopus euro- } \\
\text { paeus, Juncus sp., Rubus sp.) sclerotia of Cenococcum geophilum }\end{array}$ & $\mathrm{Z} 2 / 4$ \\
\hline $1.45-1.50$ & $\begin{array}{l}\text { Carex sp. } 80 \% \text { (mainly roots), Brown mosses 6\%, Phragmites australis 3\% (roots and rhizomes), wood 3\% (including } \\
\text { Alnus glutinosa and Betula sp.), other } 8 \% \text { (including: fruits of Betula sect. Albae, rhizomes of Equisetum sp. and sclerotia } \\
\text { of Cenococcum }\end{array}$ & \\
\hline
\end{tabular}

\section{Discussion}

The analyses of plant macrofossil remains from the peat deposit at Zapadź indicate that the key role in the building up of the peatland at most stages of its development was played by various rushes with a variable proportion of mosses. Accumulation of wood peat and the species composition of the herbaceous remains found in the material also indicate the periodic growth of alder forests. They dominated in the past when wet conditions occurred, evidenced by peat layers containing macrofossils of species such as Sphagnum spp. and Menyanthes trifoliata which are characteristic of habitats where the water table is relatively high and stable (Kłosowski and Kłosowski 2007; Table 1). The occurrence of Menyanthes trifoliata $(3.30-3.35 \mathrm{~m}, 3.45-3.50 \mathrm{~m})$ in the $\mathrm{Z} 1$ profile may also indicate periodic flooding of the mire surface. The occurrence of Cenococcum geophilum sclerotia also suggest periodic drying of the mire surface (Andersson et al. 2011), for example layers at 1.35-1.40 m and 1.55-1.60 m (Z1 profile) and the $1.00-1.50-\mathrm{m}$ layer in the $\mathrm{Z} 2$ profile.

High values of $n-\mathrm{C}_{23}$ and $n-\mathrm{C}_{25}$ are associated with the occurrence of Sphagnum species (Table 1; e.g. Z1/2 sample) for which these chain lengths are characteristic (Nott et al. 2000; Pancost et al. 2002; Nichols et al. 2006). During analysis of the results, an increased amount of $n-C_{23}$ and $n-C_{25}$ was noted in the all the samples. Individual results vary in their content of $n-\mathrm{C}_{23}$ and $n$ - $\mathrm{C}_{25}$ alkanes (e.g. Z1/7 sample) and, furthermore, high values of $n-\mathrm{C}_{27}$ alkanes were observed. The unexpected distributions seen can indicate that some plant species or tissues are more important sources of $n$-alkanes than others, such that they dominate the $n$-alkane distributions even when their macrofossil remains are not abundant. For similar dependencies take note of, inter alia, Pancost et al. (2002). Higher plants often contain $n$-alkanes, typically with the highest contents of $n-\mathrm{C}_{29}, n-\mathrm{C}_{31}$, and $n$ - $\mathrm{C}_{33}$, while $n$ - $\mathrm{C}_{23}$ and $n-\mathrm{C}_{25}$ are minor as demonstrated in other studies, e.g. Eglinton and Hamilton (1967) and Schellekens and Buurman (2011). The data analysis showed a discrepancy in the occurrence of $n-\mathrm{C}_{\max }$ and peat-forming plants in individual layers. An example is sample $\mathrm{Z} 1 / 8$ whose contents are mainly brown mosses. However, high values of $\mathrm{C}_{27} n$-alkane $\left(\mathrm{C}_{\max 27}\right)$ were observed at this depth. The reason for such a high content of $\mathrm{C}_{27} \mathrm{n}$-alkane may be the presence Carex spp. in the species composition. The relationship of this $n$-alkane with the presence of Carex spp. remains was also indicated by Ficken et al. (1998) and Ronkainen et al. (2013). The incompatibilities described may be related to the presence of partially decomposed macrofossils and the presence of plant species distinguished by an abundance of lipids in the peat (Pancost et al. 2002; Schellekens and Buurman 2011). Whereas for the $\mathrm{Z} 1 / 7$ sample, $\mathrm{C}_{\max }$ was obtained with a domination of $n-\mathrm{C}_{21}$, and this seems difficult to explain since the main plant component at this depth is composed of Carex spp (83\%; Table 1). Such a result may be the effect of aerobic degradation which this causes chain length reduction in organic matter of peat, assuming that there is no preferential decay of $n$-alkanes with a specific chain length (Buurman et al. 2006; Schellekens et al. 2009). Chain length reduction may cause a relative increase in $n$-alkanes with a mid-chain length (provided that longer chain 
a

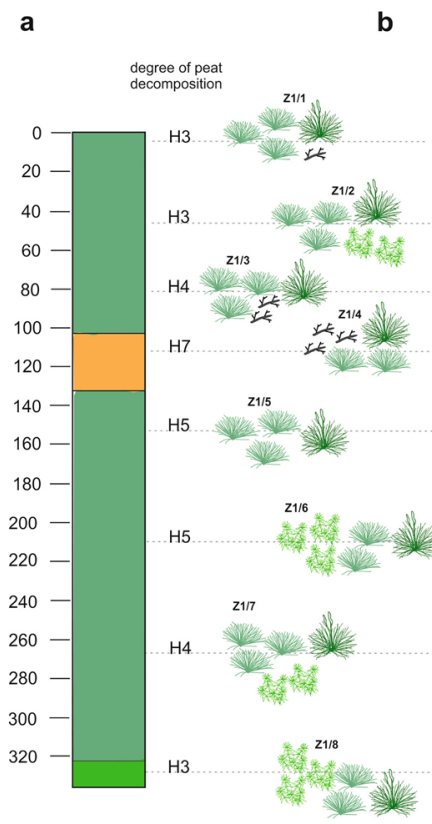

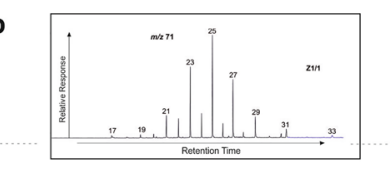
c<smiles>CCC</smiles>

$\mathrm{CPI}$

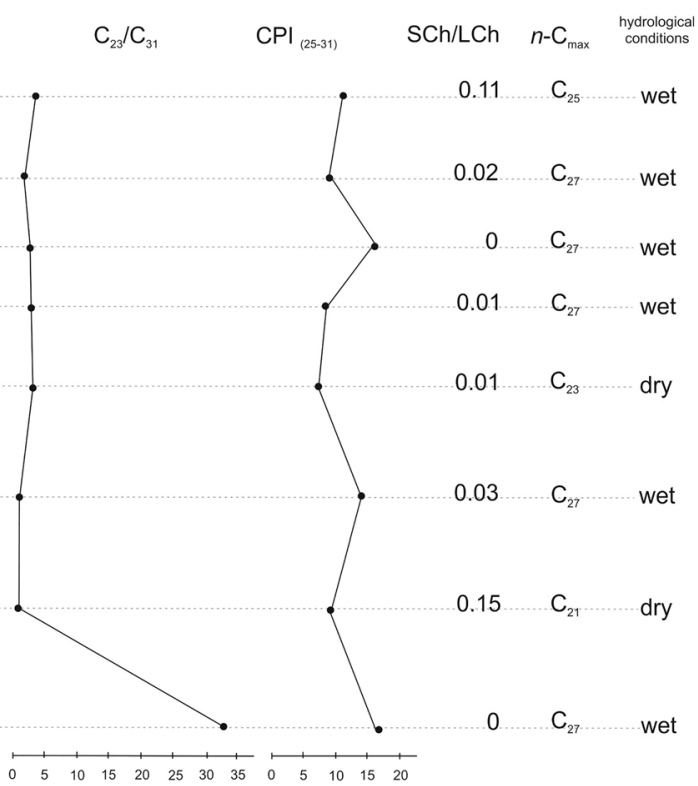

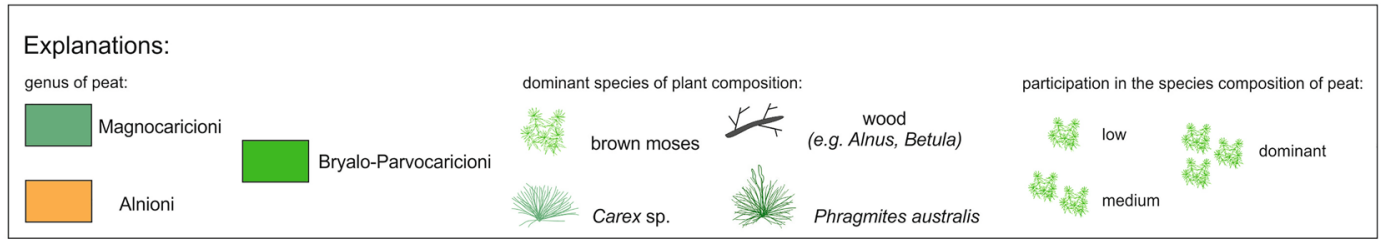

Fig. 2 Description of the peat samples from the $\mathrm{Z} 1$ core and their classification (according to Tołpa et al. 1971) and the variation of the geochemical proxies. a The variance of peat, taking into account the degree of decomposition and the share of dominant species of peat- forming plants, $\mathbf{b}$ n-Alkane distribution in selected samples. Numbers over the peaks refer to the carbon number in a molecule. c Geochemical proxies based on the distribution of n-alkanes lengths were initially dominant; Schellekens and Buurman 2011). The result obtained could also be influenced by the degree of peat decomposition, which was defined as average in the layer analysed (H4; Fig. 2a). Peat decomposition can interfere with the interpretation of primary plant chemistry, which can lead to conflicting conclusions. Extensive results presented in Schellekens and Buurman (2011) show that correct interpretation requires a combination of markers or their association with other proxies (e.g. $n$-alkenes). It may also help to compare the distribution of $n$-alkanes in different peat fractions, highlighting the influence of peat degradation leading to chain length changes.

This type of data indicates possible restrictions in the application of the $n$-alkane analysis as the only method of testing for environmental changes on peatlands. However, they do not exclude its use in multi-proxy studies along with classical palaeobotanical and palaeozoological methods.

In the $\mathrm{Z} 1$ and $\mathrm{Z} 2$ profiles, $n-\mathrm{C}_{\max }$ values are dominant for $\mathrm{C}_{27} n$-alkanes. An example is a Z1/4 sample in which the species composition contains dominant wood and bark of Alnus glutinosa and Betula sp. strongly decomposed. This is consistent with the findings of Zech et al. (2010) who indicated that for $n-\mathrm{C}_{27}$ the maximum is related to the presence of Betula spp. and Salix spp material. Such a relationship between the plant species composition and chain length of the $n$-alkane is also confirmed by Andersson et al. (2011). A significant difference was observed within the $n-\mathrm{C}_{23}$ content in the study profiles. Such variability can be interpreted as reflecting the diversity of the Sphagnum species. A similar relationship was also indicated by Nott et al. (2000), Bingham et al. (2010), and Fabiańska et al. (2014).

Differentiation within the $\mathrm{C}_{23} / \mathrm{C}_{31}$ ratio, and especially a very high value in the Z1/8 sample (Fig. 2c), can indicate a sudden change in environmental conditions (higher water table) during peatland formation. This is confirmed by the presence of Menyanthes trifoliata seeds in the sediment which prefer a high water level (Kłosowski and Kłosowski 2007). Low values in, e.g. the Z1/7 and Z2/4 samples, can instead suggest stable conditions - a relatively low water level in the Zapadź peatland. Plants recorded in the profiles also have a huge influence on low values of the $n-\mathrm{C}_{23} / n-\mathrm{C}_{31}$ ratio. The higher vascular plants, which dominate in the profiles (e.g. Carex spp., Eriophorum 
a

b

c
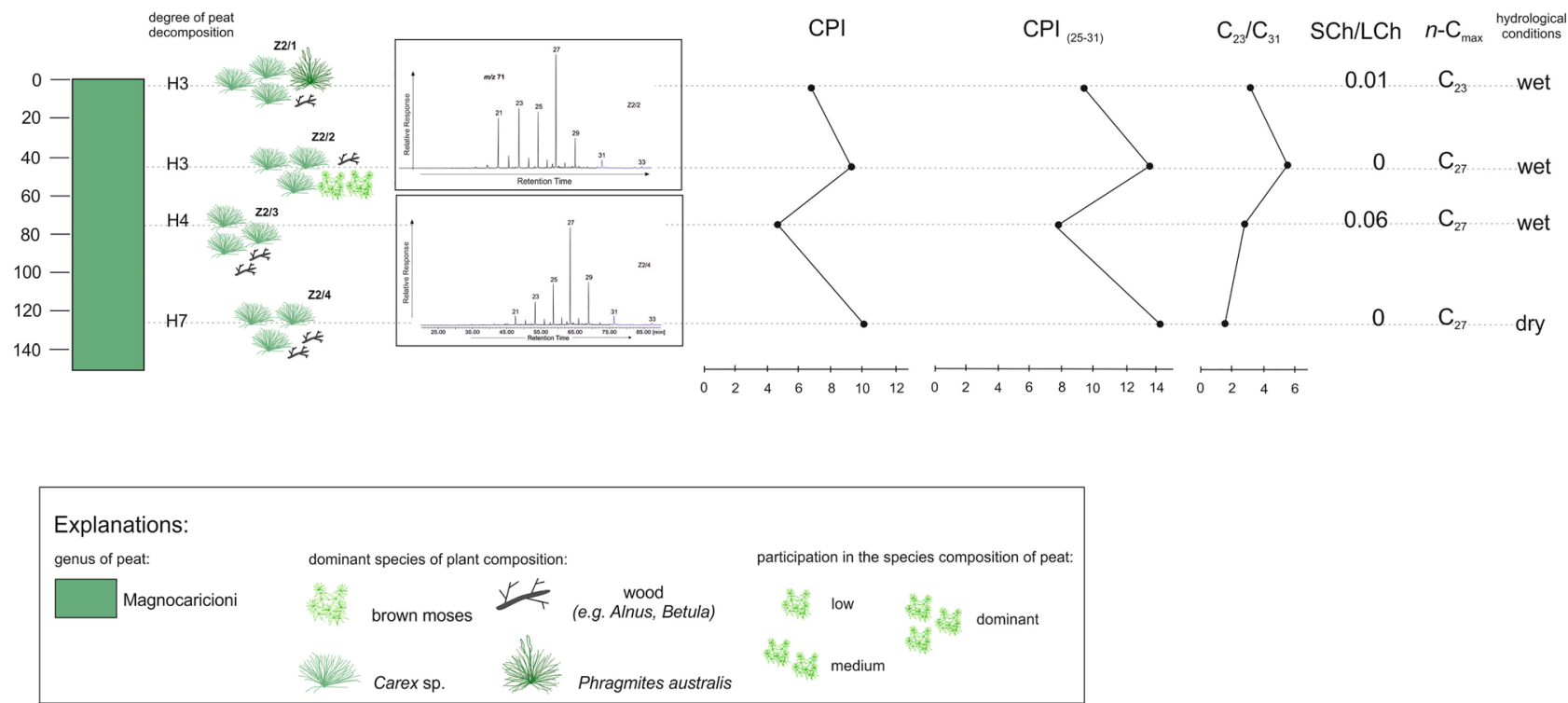

Fig. 3 Description of the peat samples from the Z2 core and their classification (according to Tołpa et al. 1971) and the variation of the geochemical proxies. a The variance of peat, taking into account the degree of decomposition and the share of dominant species of peat-

vaginatum, Phragmites australis, Betula sect. Albae), have an influence on the low value of the $\mathrm{C}_{23} / n-\mathrm{C}_{31}$ ratio. This is confirmed by the research of Ronkainen et al. (2013). By contrast, the growing share of mosses (Figs. 2c, 3c) contributed to an increase in the value of this indicator, as seen in the studies by Nott et al. (2000) and Bingham et al. (2010). The variance of the $n-\mathrm{C}_{23} / n-\mathrm{C}_{31}$ ratio is also likely to result from changes resulting from the presence of Sphagnum spp. and brown mosses as components of peat, which was suggested by the results (e.g. Bingham et al. 2010; Pancost et al. 2002). These data confirm the results of Spearman's rank correlation coefficient $r_{s}=0.83$ forming plants, $\mathbf{b}$ n-Alkane distribution in selected samples. Numbers over the peaks refer to the carbon number in a molecule. c Geochemical proxies based on the distribution of n-alkanes

( $p=0.03$, with the assumed significance level $p<0.05)$, indicating a very close relationship between brown mosses and the variance of the $n-C_{23} / n-C_{31}$ ratio.

The resulting CPI values are higher than 1 (Figs. 2c, 3c), indicating a predominance of odd over even $n$-alkane homologues (Schellekens and Buurman 2011). This indicator can be used as a diagnostic for determining the direction of the main biogenic sources of $n$-alkanes (Ruan et al. 2018). High values of the CPI indicate a high input of cuticular waxes of higher vascular plants into peats and a low maturity of organic matter (Fabiańska et al. 2014). The species composition of the study

Table 3 Individual $n$-alkane homologue data $\left(\mathrm{C}_{19}-\mathrm{C}_{35}\right)$ for peat horizons. Relative abundances normalized to major peak $=100$

\begin{tabular}{|c|c|c|c|c|c|c|c|c|c|c|c|c|c|c|c|c|c|}
\hline Sample & $\mathrm{C}_{19}$ & $\mathrm{C}_{20}$ & $\mathrm{C}_{21}$ & $\mathrm{C}_{22}$ & $\mathrm{C}_{23}$ & $\mathrm{C}_{24}$ & $\mathrm{C}_{25}$ & $\mathrm{C}_{26}$ & $\mathrm{C}_{27}$ & $\mathrm{C}_{28}$ & $\mathrm{C}_{29}$ & $\mathrm{C}_{30}$ & $\mathrm{C}_{31}$ & $\mathrm{C}_{32}$ & $\mathrm{C}_{33}$ & $\mathrm{C}_{34}$ & $\mathrm{C}_{35}$ \\
\hline $1 / 1$ & 1.2 & 4.0 & 23.1 & 19.1 & 9 & 22.3 & 100 & 11.6 & 1 & 0 & 34.3 & 3.6 & 19.5 & 2 & 8 & 0 & 0.0 \\
\hline $\mathrm{Z} 1 / 2$ & 3 & 2 & 45 & 12.5 & 93 & 14 & 78 & 11 & 100 & 11.5 & 79.5 & 4 & 45 & 2 & 13.5 & 0.0 & 0.0 \\
\hline $\mathrm{Z} 1 / 3$ & 0.0 & 0.0 & 26.3 & 5.4 & 45.5 & 4.8 & 40.7 & 5.1 & 100 & 5.6 & 42.4 & 0.0 & 12.7 & 0.0 & 0.0 & 0.0 & 0.0 \\
\hline $\mathrm{Z} 1 / 4$ & 1.5 & 1.5 & 31.5 & 13.1 & 55.4 & 13.5 & 51.7 & 11.6 & 100 & 10.5 & 68.5 & 1.9 & 16.5 & 0.4 & 3.7 & 0.0 & 0.0 \\
\hline $\mathrm{Z} 1 / 5$ & 0.0 & 5.2 & 73.9 & 22.7 & 100 & 17.5 & 74.4 & 15.2 & 73.5 & 5.2 & 60.7 & 1.9 & 24.6 & 1.9 & 11.8 & 0.0 & 0.0 \\
\hline $\mathrm{Z} 1 / 6$ & 5.1 & 5.1 & 23.6 & 13 & 94 & 12 & 68.1 & 8.8 & 100 & 6 & 61.6 & 1.4 & 64.4 & 1.4 & 14.8 & 0.0 & 0.0 \\
\hline $\mathrm{Z} 1 / 7$ & 13.6 & 11.1 & 100 & 22.8 & 8.2 & 11.7 & 42.7 & 7.6 & 63.3 & 2.8 & 24.1 & 0.9 & 7.6 & 0.0 & 0.0 & 0.0 & 0.0 \\
\hline $\mathrm{Z} 1 / 8$ & 0.0 & 0.5 & 22.2 & 6.6 & 53.6 & 4.2 & 42.2 & 4.2 & 100 & 4.2 & 33.2 & 0.8 & 1.3 & 0.0 & 0.0 & 0.0 & 0.0 \\
\hline $\mathrm{Z} 2 / 1$ & 1.8 & 1.8 & 56.2 & 16.4 & 100 & 16.4 & 87.7 & 12.3 & 88.1 & 6.4 & 54.3 & 1.4 & 26.9 & 1.8 & 2.3 & 0.0 & 0.0 \\
\hline $\mathrm{Z} 2 / 2$ & 0.7 & 1.4 & 49.1 & 10.7 & 76.5 & 8.3 & 48.4 & 6.2 & 100 & 5.2 & 38.1 & 0.7 & 11.8 & 0.3 & 2.4 & 0.0 & 0.0 \\
\hline $\mathrm{Z} 2 / 3$ & 5.9 & 6.3 & 61.5 & 19.6 & 39.6 & 13 & 40 & 12.6 & 100 & 6.3 & 53.3 & 3.7 & 12.2 & 0.0 & 0.0 & 0.0 & 0.0 \\
\hline $\mathrm{Z} 2 / 4$ & 0.3 & 0.8 & 10.5 & 4.7 & 30.7 & 5.5 & 34.8 & 6.1 & 100 & 6.1 & 59.4 & 1.1 & 16.9 & 0.3 & 2.5 & 0.0 & 0.0 \\
\hline
\end{tabular}


samples is dominated mostly by Carex spp. (e.g. Z1/2, Z1/5, $\mathrm{Z} 2 / 3$ ) and Phragmites australis (e.g. Z1/5, Z2/1). The presence of these species in sediments is associated with the presence of medium- and long-chain $n$-alkanes (Nott et al. 2000; Nichols et al. 2006). The results of Spearman's correlation showed a significant relationship between a high content of Carex spp. and the value of $\mathrm{C}_{27}$ in the sample, $\mathrm{rs}=0.45$ ( $p=0.03$, with an assumed significance level of $p<0.05$ ). A similar relationship was observed in the case of Phragmites australis, which also shows a high correlation with $\mathrm{C}_{27}(\mathrm{rs}=0.66), \mathrm{C}_{29}(\mathrm{rs}=0.67)$, and $\mathrm{C}_{31}(\mathrm{rs}=0.68)$ at a level of significance of $p<0.05$. For the remaining medium- and long-chain $\mathrm{n}$ alkanes, no significant correlation was found. The genesis of high CPI values (Figs. 2c, 3c) can be explained by comparing them with the species composition (Table 1). There is a correlation between a high proportion of vascular plants and higher CPI values in most samples (e.g. Z1/3, Z1/6, Z2/4). It is well illustrated, for example, by the significant correlation between the share of wood fragments or tree leaves in the sediment and the share of $n-\mathrm{C}_{29}$ ( $\mathrm{rs}=0.68$, $p=0.0004$ ). The other samples do not show such clear dependencies. This seems to be related to the variation in the production of $n$-alkanes in different parts of specific plant species. An example is vascular plant species whose leaves show a higher concentration of $n$-alkanes than Sphagnum and other moss species (Ficken et al. 1998, 2000). The predominance of long-chain $n$-alkanes over short-chain in the study profiles is characteristic of terrestrial organic matter (Peters and Moldowan 1993). This is reflected in the botanical composition of the peat samples.

The interpretation of the results on $n$-alkane content in high-moor peat with regard to low-moor peat is open to debate if based on data in the literature. On account of the small number of studies on biomarkers occurring in transitional and lowmoor peat, some authors use the same markers as occur with high-moor peat (Andersson et al. 2011; Andersson and Meyers 2012; Pastukhov et al. 2018).

However, the results on the contents of alkanes in low-moor peat presented by Pastukhov et al. (2018) present similar conclusions to the data which were obtained from the Zapadź peatland. The peatlands in north-eastern Europe and on the Zapadź site were dominated by long-chain $n$-alkane homologues $\left(\mathrm{C}_{27}, \mathrm{C}_{29}\right)$ whose bioproducers are higher vascular plants. In the sites described by Pastuchow et al. (2018) and the Zapadź peatland, a large proportion of homologous $n$-alkanes of medium chain length $\left(\mathrm{C}_{23}, \mathrm{C}_{25}\right)$ were also found.

\section{Conclusions}

The results of the palaeobotanical analysis made it possible to determine the hydrological changes in the Zapadź peatland. During the formation of the Zapadź peatland, wet conditions mainly prevailed with slight drying and a fire episode.
The $n$-alkanes found in individual layers were characteristic for peatland vegetation groups. The results indicate that the content of $n$-alkanes in general reflects vegetation changes in the individual phases of peatland formation.

The degree of peat decomposition had no significant effect on the distribution of $n$-alkanes. Only in the case of individual samples can it be assumed that the influence of the degree of degradation could have been significant. The results do not provide a clear assessment of the intensity of the impact on the distribution of the peat's right to distribute the $n$-alkanes. In the future, research should be supplemented with a combination of markers or an association with the other proxies (e.g. $n$-alkenes) proposed in the publication Schellekens and Buurman (2011).

Research has shown that analysis of the composition of $n$-alkanes as biomarkers is generally a good tool enabling the reconstruction of vegetation changes and hydrological conditions, not only in ombrotrophic peatlands, but also in low-moor and transitional peatlands. Thus, this may be used in studies on the history of river valley ecosystems where ombrotrophic peatlands are usually absent. However, due to its limitations, it should only be used as a valuable supplement to classical palaeobotanical and palaeozoological methods.

Acknowledgements We thank Prof. Leszek Marynowski and PhD Michał Bucha (University of Silesia, Katowice, Poland) for helpful discussions and GC-MS analysis. Special thanks go also to Seamus and Karolina Mulrooney for language correction.

Open Access This article is licensed under a Creative Commons Attribution 4.0 International License, which permits use, sharing, adaptation, distribution and reproduction in any medium or format, as long as you give appropriate credit to the original author(s) and the source, provide a link to the Creative Commons licence, and indicate if changes were made. The images or other third party material in this article are included in the article's Creative Commons licence, unless indicated otherwise in a credit line to the material. If material is not included in the article's Creative Commons licence and your intended use is not permitted by statutory regulation or exceeds the permitted use, you will need to obtain permission directly from the copyright holder. To view a copy of this licence, visit http://creativecommons.org/licenses/by/4.0/.

\section{References}

Andersson RA, Kuhry P, Meyers P, Zebühr Y, Crill P, Mörth M (2011) Impacts of paleohydrological changes on n-alkane biomarker compositions of a Holocene peat sequence in the eastern European Russian Arctic. Org Geochem 42:1065-1075. https://doi.org/10. 1016/j.orggeochem.2011.06.020

Andersson RA, Meyers PA (2012) Effect of climate change on delivery and degradation of lipid biomarkers in a Holocene peat sequence in the eastern European Russian Arctic. Org Geochem 53:63-72. https://doi.org/10.1016/j.orggeochem.2012.05.002

Baas M, Pancost R, Geel B, Sinninghe Damsté JS (2000) A comparative study of lipids in Sphagnum species. Org Geochem 31:535541. https://doi.org/10.1016/S0146-6380(00)00037-1 
Balascio NL, D'Andrea WJ, Anderson RS, Wickler S (2018) Influence of vegetation type on n-alkane composition and hydrogen isotope values from a high latitude ombrotrophic bog. Org Geochem 121:48-57. https://doi.org/10.1016/j.orggeochem.2018.03.008

Bastow TP, van Aarssen BGK, Lang D (2007) Rapid small-scale separation of saturate, aromatic and polar components in petroleum. Org Geochem 38:1235-1250. https://doi.org/10.1016/j.orggeochem. 2007.03.004

Bingham EM, McClymont EL, Väliranta M, Roberts MD, Chambers Z, FM, Pancost RD, Evershed RP, (2010) Conservative composition of n-alkane biomarkers in Sphagnum species: implications for palaeoclimate reconstruction in ombrotrophic peat bogs. Org Geochem 41:214-220. https://doi.org/10.1016/j.orggeochem.2009.06.010

Buurman P, Nierop KGJ, Pontevedra-Pombal X, Martínez-Cortizas A (2006) Molecular chemistry by pyrolysis-GC/MS of selected samples of the Penido Vello peat deposit, Galicia, NW Spain. In: Martini IP, Martínez-Cortizas A, Chesworth W (eds) Peatlands: Evolution and Records of Environmental and Climate Change. Elsevier, Amsterdam, pp 217-240

Charman DJ (2002) Peatlands and environmental change. John Wiley and Sons, West Sussex

Eglinton G, Hamilton RG (1967) Leaf epicuticular waxes. Science 156:1322-1335

Fabiańska M, Szymczyk A, Chłapik M (2014) Fossil fuel compounds from fly dust in recent organic matter of southern Poland peats. Chem Erde-Geochem 74:237-250. https://doi.org/10.1016/j. chemer.2013.07.006

Ficken K, Barber K, Eglington G (1998) Lipid biomarker, $\delta 13 \mathrm{C}$ and plant macrofossil stratigraphy of a Scottish montane peat bog over the last two millennia. Org Geochem 28:217-237. https://doi.org/ 10.1016/S0146-6380(97)00126-5

Ficken KJ, Li B, Swain DL, Eglinton G (2000) An n-alkane proxy for the sedimentary input of submerged/floating freshwater aquatic macrophytes. Org Geochem 31:745-749. https://doi.org/10.1016/ S0146-6380(00)00081-4

Gabov DN, Beznosikov VA, Gruzdev IV, Yakovleva EV (2017) Accumulation of $\mathrm{n}$-alkanes and arboxylic acids in peat mounds. Eurasian Soil Sci 50(10):1138-1153. https://doi.org/10.1016/S01466380(00)00081-4

Kłosowski S, Kłosowski G (2007) Flora Polski. Rośliny wodne i bagienne. MULTICO Ofcyna Wydawnicza, Warszawa (in Polish)

Kotarba M, Kowalski A, Więcław D (1994) Nowa metoda obliczeń wskaźnika CPI i wykorzystanie dystrybucji n-alkanów i izoprenoidów prospekcji naftowej - instrukcja metodyczna analiz z zakresu geochemii organicznej dla potrzeb poszukiwań naftowych. Materiały wewnętrzne AGH, pp. 82-91 (in Polish)

Maliński E, Witkowski A (1988) Węglowodory jako biomarkery źródła ich pochodzenia, znaczenie i wykorzystanie w geochemii organicznej. Przegląd Geol 36:25-32 ((in Polish))

Nichols JE, Booth RK, Jackson ST, Pendall EG, Huang Y (2006) Paleohydrologic reconstruction based on n-alkane distributions in ombrotrophic peat. Org Geochem 37:1505-1513. https://doi. org/10.1016/j.orggeochem.2006.06.020

Nichols JE, Walcott M, Bradley R, Pilcher J, Huang Y (2009) Quantitative assessment of precipitation seasonality and summer surface wetness using ombrotrophic sediments from an Arctic Norwegian peatland. Quat Res 72:443-451. https://doi.org/10.1016/j.yqres. 2009.07.007
Nott CJ, Xie S, Avsejs LA, Maddy D, Chambers FM, Evershed RP (2000) $n$-Alkane distributions in ombrotrophic mires as indicators of vegetation change related to climatic variation. Org Geochem 31:231-235. https://doi.org/10.1016/S0146-6380(99)00153-9

Pancost RD, Baas M, Geel B, Sinninghe Damsté JS (2002) Biomarkers as proxies for plant inputs to peats: an example from a sub-boreal ombrotrophic bog. Org Geochem 33:675-690. https://doi.org/10. 1016/S0146-6380(02)00048-7

Pastukhov AV, Knoblauch C, Yakovleva EV, Kaverin DA (2018) Markers of soil organic matter transformation in permafrost peat mounds of northeastern Europe. Eurasian Soil Sci 51(1):42-53. https://doi.org/10.1134/S1064229318010131

Peters KE, Moldowan JM (1993) The biomarkers guide. Interpreting molecular fossils in petroleum and ancient sediments. Prentice Hall, Englewood Cliffs, New Jersey

Ronkainen T, McClymont EL, Väliranta M, Tuittila ES (2013) The $n$-alkane and sterol composition of living fen plants as a potential tool for palaeoecologicalstudies. Org Geochem 59:1-9. https:// doi.org/10.1016/j.orggeochem.2013.03.005

Ruan X, Ye H, Lu Q, Yang Z (2018) Historical record, source, and toxicity assessment of sedimentary organic matter using molecular composition of hydrocarbons in an urban lake, Wuhan. China j Soils Sediments 18:2081-2092. https://doi.org/10.1007/ s11368-018-1956-9

Rybicki M, Marynowski L, Misz-Kennan M, Simoneit B (2016) Molecular tracers preserved in Lower Jurassic "Blanowice brown coals" from southern Poland at the onset of coalification: organic geochemical and petrological characteristics. Org Geochem 102:77-92. https://doi.org/10.1016/j.orggeochem. 2016.09.012

Rydin H, Jeglum JK (2013) The Biology of Peatlands. Biology of Habitats. Oxford Scholarship. https://doi.org/10.1093/acprof:osobl/ 9780199602995.001.0001

Schellekens J, Buurman P (2011) $n$-Alkane distributions as palaeoclimatic proxies in ombrotrophic peat: The role of decomposition and dominant vegetation. Geoderma 163(3):112-124. https://doi. org/10.1016/j.geoderma.2011.05.012

Schellekens J, Buurman P, Pontevedra-Pomba X (2009) Selecting parameters for the environmental interpretation of peat molecular chemistry—a pyrolysis-GC/MS study. Org Geochem 40:678-691. https://doi.org/10.1016/j.orggeochem.2009.03.006

Tołpa S, Jasnowski M, Pałczyński A (1971) New classification of peat based on phytosociological methods. Bulletin International Peat Society 2:9-14

Zhang Y, Meyers PA, Gao C, Liu X, Wang J, Guoping Wang G (2017) Holocene climate change in northeastern China reconstructed from lipid biomarkers in a peat sequence from the Sanjiang Plain. Org Geochem 113:105-114. https://doi.org/10.1016/j. orggeochem.2017.07.018

Zech M, Andreev A, Zech R, Müller S, Hambach U, Frechen M, Zech W (2010) Quaternary vegetation changes derived from a loess-like permafrost palaeosol sequence in northeast Siberia using alkane biomarker and pollen analyses. Boreas 39:540-550. https://doi. org/10.1111/j.1502-3885.2009.00132.x

Publisher's Note Springer Nature remains neutral with regard to jurisdictional claims in published maps and institutional affiliations. 